\title{
Criteria of instability of copper and aluminium perfect crystals subjected to elastic deformation in the temperature range $0-400 \mathrm{~K}$
}

\author{
A. V. Zinovev ${ }^{1,2}$, A. M. Iskandarov ${ }^{3}$, S. V. Dmitriev ${ }^{\dagger, 4,5}$, A. I. Pshenichnyuk $^{4}$ \\ †dmitriev.sergey.v@gmail.com \\ ${ }^{1}$ SCK • CEN, Institute for Nuclear Materials Science, Boeretang 200, Mol, 2400, Belgium \\ ${ }^{2}$ iMMC, Université catholique de Louvain, Av. Georges Lemaître 4, Louvain-la-Neuve, 1348, Belgium \\ ${ }^{3}$ Institute of Industrial Science, The University of Tokyo, Meguro-ku, Tokyo, 153 - 8505, Japan \\ ${ }^{4}$ Institute for Metals Superplasticity Problems RAS, 39 Khalturin St., Ufa, 450001, Russia \\ ${ }^{5}$ National Research Tomsk State University, 36 Lenin Av., Tomsk, 634050, Russia
}

Polycrystalline metals have flow stress two to three orders of magnitude lower than the theoretical shear strength estimated by Frenkel model. This significant strength difference is primarily due to the presence of defects, such as dislocations and grain boundaries. However, it was experimentally found that defect-free nanoscale objects (whiskers, nanopillars, etc.) can exhibit strength close to the theoretical limit. With the development of nanotechnology, interest in the study of the theoretical strength of metals and alloys has grown significantly. It is important to find reliable criteria of lattice instability when homogeneous nucleation of defects begins during deformation of an ideal crystal lattice. Note that the Frenkel estimation does not take into account thermal vibrations of atoms and attempts are being made to take into account the effect of temperature on the theoretical strength of defect-free crystals. In this paper, using molecular dynamics simulation, we study shear deformation in the direction of (111)[11 $\overline{2}$ ] for single crystals of copper and aluminum in the temperature range from 0 to $400 \mathrm{~K}$. Lattice instability was evaluated using two criteria: (i) macroscopic criterion, which is related to the loss of positive definiteness of the stiffness tensor, and (ii) a microscopic criterion related to the formation of a stacking fault, which leads to a drop of the applied shear stress. It was demonstrated that both criteria are consistent at low temperatures, but the macroscopic criterion is less reliable at higher temperatures.

Keywords: theoretical strength, stability criterion, copper, aluminum.

УДК: 538.913

\section{Критерии неустойчивости бездефектных кристаллов меди и алюминия, подвергнутых упругой деформации в интервале температур 0-400 K}

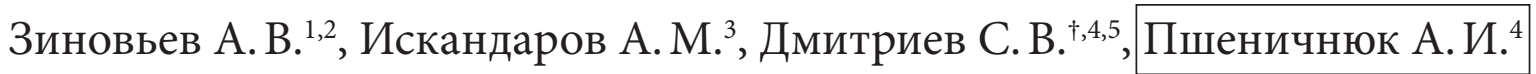 \\ ${ }^{1}$ SCK CEN, Nuclear Materials Science Institute, Boeretang 200, Mol, 2400, Belgium \\ ${ }^{2}$ Universite Catholique de Louvain, Place de L’Universite 1, B-1348, Louvain-la-Neuve, Belgium \\ ${ }^{3}$ Institute of Industrial Science, The University of Tokyo, Meguro-ku, Tokyo, 153-8505, Japan \\ ${ }^{4}$ Институт проблем сверхпластичности металлов РАН, ул. Халтурина, 39, Уфа, 450001, Россия
} ${ }^{5}$ Национальный исследовательский Томский государственный университет, пр. Ленина, 36, Томск, 634050, Россия

Металлы в поликристаллической форме обладают напряжением течения на два-три порядка ниже теоретического предела прочности, оцененного Френкелем. Столь значительное снижение прочности обусловлено наличием в металлах дефектов кристаллической структуры, прежде всего, дислокаций и границ зерен. Экспериментально установлено, что бездефектные наноразмерные объекты (нановолокна, наностолбики и др.) показывают прочность близкую к теоретическому пределу. С развитием нанотехнологий интерес к изучению теоретической прочности металлов и сплавов значительно вырос. Важным является вопрос критерия достижения теоретического предела прочности при гомогенном зарождении дефектов в ходе деформирования идеальной кристаллической решетки. Отметим, что оценка Френкеля не учитывает тепловых колебаний атомов, и в настоящее 
время предпринимаются попытки учета влияния температуры на теоретическую прочность бездефектных кристаллов. В данной работе, спомощью метода молекулярной динамики, изучается деформация сдвига в направлении (111) $[11 \overline{2}]$ монокристаллов меди и алюминия в интервале температур от 0 до 400 К. Сравниваются два критерия неустойчивости упругого деформирования: (i) макроскопический, отслеживающий положительную определенность тензора жесткости, и (ii) микроскопический критерий, отслеживающий образование дефекта упаковки, которое приводит к резкому падению напряжения сдвига. Продемонстрировано, что оба критерия согласуются при низкой температуре, но макроскопический критерий является менее надежным при высоких температурах.

Ключевые слова: теоретическая прочность, критерий устойчивости, медь, алюминий.

\section{Introduction}

It is well known that the crystal lattice defects, especially dislocations and grain boundaries, are responsible for a striking difference (several orders of magnitude) between the theoretical strength of crystals, estimated by Frenkel, and the strength of real construction and functional materials. However, the strength of whiskers measured in the 1950s turned out to nearly reach the theoretical Frenkel limit [1]. Also, experiments on nano-wire bending and nano-pillar compression demonstrated their extreme strength when the dislocations in the sample were absent, scarce or immobile. For example, the yield strength of a gold nanowire with a diameter of $40 \mathrm{~nm}$ was estimated to be $5.6 \mathrm{GPa}$ [2], the Frenkel theoretical strength being 4.1-6.1 GPa. The critical shear stress of aluminum was estimated in nanoindentation experiments equal to 2.3 GPa [3], which is close to the theoretical strength of $2.84 \mathrm{GPa}$ [4]. Experiments on uniaxial compression of nanoscale samples showed that the yield strength increases with the decrease of its diameter according to the power law $\sigma_{\mathrm{y}} \sim d^{-\xi}$ in the case of presence of dislocations [5-9], while in their absence the material yield strength does not depend on the sample diameter and is close to the theoretical limit [10-13].

It is known that certain optical, electromagnetic or acoustic properties of a crystal continuously change with the increase of applied elastic deformation. Since a larger elastic deformation can be applied to the nanoscale crystals compared to the conventional materials, the available room for the property tuning is expanded as well.

In practice, it is necessary to understand the limits of mechanical stability of nanocrystals subjected to elastic deformation. As experimental investigation is very labourand time-consuming, an alternative is to perform computer simulations using various approaches, such $a b$ initio or molecular dynamics. In the first works dedicated to this problem, the main goal was to determine the theoretical strength [14]. Nowadays, the research is focused on the failure of nanocrystals at applied stress below the theoretical limit, the possible reasons being the effect of twins and grain boundaries $[15,16]$ or the sample crystallographic orientation with respect to the loading direction [17-20]. The effect of compression and tension on the theoretical strength of covalent crystals was also studied [21-23].

The effect of temperature on the theoretical strength of aluminium $(\mathrm{Al})$ and copper $(\mathrm{Cu})$ crystals was studied with the help of molecular dynamics (MD) [24], demonstrating a linear decrease in the critical shear stress with temperature. The moment of the crystal lattice stability loss under applied shear deformation was determined by a sudden structure transformation, corresponding to the stacking fault formation, which is also reflected in the stress-strain curve as a stress drop.

The present paper explores another, macroscopic, criterion of mechanical stability of lattice subjected to deformation, which is based on the positive definiteness of the stiffness tensor and was successfully tested for silicon [25], where a good match with the results of $a b$ initio calculations at $0 \mathrm{~K}$ was demonstrated. Here the applicability of this criterion is tested at elevated temperatures up to $400 \mathrm{~K}$.

\section{Description of the computational model and stability criteria}

The $\mathrm{Cu}$ and $\mathrm{Al}$ single crystals were studied here as the most characteristic representatives of fcc metals with low and high stacking fault energy, respectively.

Our MD calculations were performed with the interatomic potentials based on the embedded-atom method (EAM), commonly used in MD simulations of metallic crystals. In particular, the potential by Mishin et al. was applied in calculations of $\mathrm{Cu}$ [26], and the potential by Zope and Mishin [27] was chosen for Al, according to the comparative study [28].

The computational cell initially had a rectangular shape in which the crystallographic directions [11 $]$, [ [110], and [111], were oriented along $x, y$, and $z$ axes, respectively. The computational cell size effect was studied and the cell containing 1296 atoms was adopted in simulations, since further increase of the cell did not affect the results [29]. Periodic boundary conditions were imposed in three perpendicular directions. The simulations were performed with the use of MDSPASS MD package developed in the University of Tokyo.

Simple shear $\tau_{x z}$ was applied in the direction of the easiest

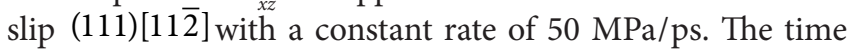
step in the MD simulations was set equal to $1 \mathrm{fs}$, which is much smaller than the typical period of atomic thermal oscillations. Prior to application of the shear stress the lattice relaxation during the first 10 ps was performed at every given temperature. The stress was controlled using the ParinelloRaman method [30].

Hooke's law for small strain, $\sigma_{i j}=C_{i j k l} \gamma_{k l}$ establishes the linear relationship between the tensors of stress $\sigma_{i j}$ and strain $\gamma_{k l}$ via the elastic constant tensor $C_{i j k l}$. Not all components of these tensors are independent due to the tensor's symmetry. Thus, Hooke's law can be rewritten in a clearer form using the Voigt notation, reducing the rank of tensors.

$$
\sigma_{w}=C_{w v} \varepsilon_{v}
$$

where $\varepsilon_{v}=\gamma_{k l}$ for normal strain components $(v=1,2,3)$ and $\varepsilon_{v}=2 \gamma_{k l}$ for shear strain components $(v=4,5,6)$. 
However, linear relationship (1) holds only for small elastic strains, whereas at larger elastic strains the tensor $C$ should be substituted with the tensor of stiffness $B$, whose components are not constant [25]

$$
B_{w v}=\frac{\partial \sigma_{w}}{\partial \varepsilon_{v}}
$$

where $v$ and $w$ are integers from 1 to 6 .

Let us describe the numerical procedure for calculation of matrix $B$ during $\mathrm{MD}$ simulation. In the course of $\mathrm{MD}$ run, the components of stiffness tensor were calculated every $100 \mathrm{fs}$ by applying a small extra strain component $\varepsilon_{v}^{+}=-\varepsilon_{v}^{-}=\varepsilon_{v}=10^{-4}$ and tracking the consequent variation of stress tensor components $\sigma_{w}^{+}$and $\sigma_{w}^{-}$. Then, the derivative in Eq. (2) was estimated as

$$
B_{w v}=\frac{\partial \sigma_{w}}{\partial \varepsilon_{v}}=\frac{\sigma_{w}^{+}-\sigma_{w}^{-}}{2 \varepsilon_{v}} .
$$

The following two criteria of the mechanical stability of a lattice are compared in the present work: (i) macroscopic one, which is defined as the positive definiteness of the stiffness tensor $B$ [25], and (ii) microscopic criterion, corresponding to a violation of atomic order in the crystal due to a stacking fault formation, which can be identified on a macroscopic scale via sudden drop of the applied shear stress. To detect the positive definiteness of matrix $B$, Sylvester's criterion was used: if all of the leading principal minors are positive then the structure is mechanically stable. A leading principal minor is the determinant of a smaller matrix, located in the upper-left corner of the matrix in question. The six leading minors calculated from the $1 \times 1,2 \times 2, \ldots, 6 \times 6$ corner matrices of the $6 \times 6$ matrix $B$, are denoted as $M_{1}, M_{2}, \ldots, M_{6}$, correspondingly. Note that $M_{1}=B_{11}, M_{2}=B_{11} B_{22}-B_{12} B_{21}$, and so on.

\section{Results and discussion}

Fig. 1 shows the crystal structure in projection on $x z$ plane before deformation (a); during elastic deformation before the stability loss (b); and after the stability loss with a stacking fault formation and sudden drop of the shear stress (c). Open and filled circles show atoms belonging to different atomic planes parallel to the image plane ( $x z$ plane).

A series of simulations in the temperature range from 0 up to $400 \mathrm{~K}$ for both $\mathrm{Al}$ and $\mathrm{Cu}$ was performed. It is important to know which leading minors reach zero first with the increase of strain, indicating that the Sylvester's criterion is not satisfied. All the leading minors of matrix $B$ are plotted in Fig. 2 for the minimal and the maximal studied temperatures, i.e., for $0 \mathrm{~K}$ (left panels) and $400 \mathrm{~K}$ (right panels). The top (bottom) panels give the results for $\mathrm{Al}(\mathrm{Cu})$. Lines of different colour are used for $M_{1}, \ldots, M_{6}$, according with the legend. Not only do the absolute values of leading minors $M_{1}, \ldots, M_{6}$ differ by orders of magnitude, but they are expressed in different units, powers of GPa. That is why in Fig. 2, the leading minors are normalized to their values at zero strain. The curves are cut at the points of the stress drop (critical points according to the microscopic criterion), which is related to the formation of a stacking fault in the deformed crystal.

From Fig. 2 one can see that the normalized values of $M_{5}$ and $M_{6}$ decrease faster compared to other leading minors in all four panels thus determining the violation of the Sylvester's criterion. For this reason, in the rest of this paper, we rely on these two leading minors in identification of the lattice stability.

Next, in Fig. 3 by dashed lines we show the evolution of $M_{5}$ (top panels) and $M_{6}$ (bottom panels) with increasing shear strain for temperatures $T=0,100,200,300$, and $400 \mathrm{~K}$ and for $\mathrm{Al}$ (left panels) and $\mathrm{Cu}$ (right panels). In addition, the evolution of shear stress with increasing shear strain is shown by the solid lines, in order to compare the two criteria of lattice stability. Note that for $\mathrm{Al}$ at $0 \mathrm{~K}$ the stress drop is observed at the value of shear strain when both $M_{5}$ and $M_{6}$ vanish which means that the macroscopic Sylvester's criterion and the microscopic criterion agree very well in this case. The same can be said about $\mathrm{Cu}$ at $0 \mathrm{~K}$, since the drop of the shear stress takes place when $M_{5}$ and $M_{6}$ decrease to nearly zero positive values. As temperature increases, the final values of the leading minors become positive; so the stacking fault is formed before the violation of the Sylvester's criterion. It can be explained by the thermally-assisted formation of the stacking fault, so that the complete macroscopic loss of lattice stability is not required; a local fluctuation of atomic arrangement can accidentally trigger the stacking fault formation.

The curves for $\mathrm{Cu}$ and $\mathrm{Al}$ in Fig. 3 behave differently: the values of both considered minors for $\mathrm{Cu}$ show much less sensitivity to temperature variation than for Al. At the same time, the critical stress and strain decrease with increase in temperature. With the temperature increasing from 0 to $400 \mathrm{~K}$, the decrease in the critical shear stress for $\mathrm{Al}$ and $\mathrm{Cu}$ is $36 \%$ and $29 \%$, respectively.

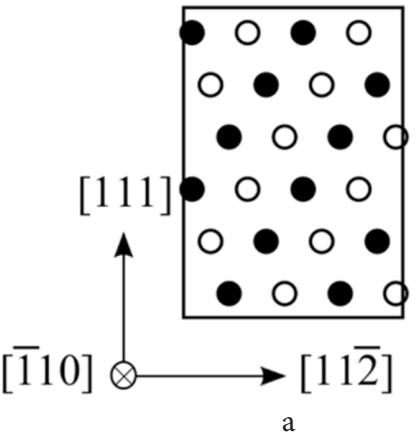

Fig. 1. Crystal structure projected on $x z$ plane before the application of shear strain (a); during elastic shear deformation, before the loss of lattice stability (b); after the loss of lattice stability with the stacking fault formation (c). Crystallographic directions [11 $\overline{2}]$, [ $\overline{1} 10]$, and [111], are oriented along $x, y$, and $z$ axes, respectively. Atoms belonging to different atomic planes parallel to the $x z$ plane are shown by open and filled circles. 

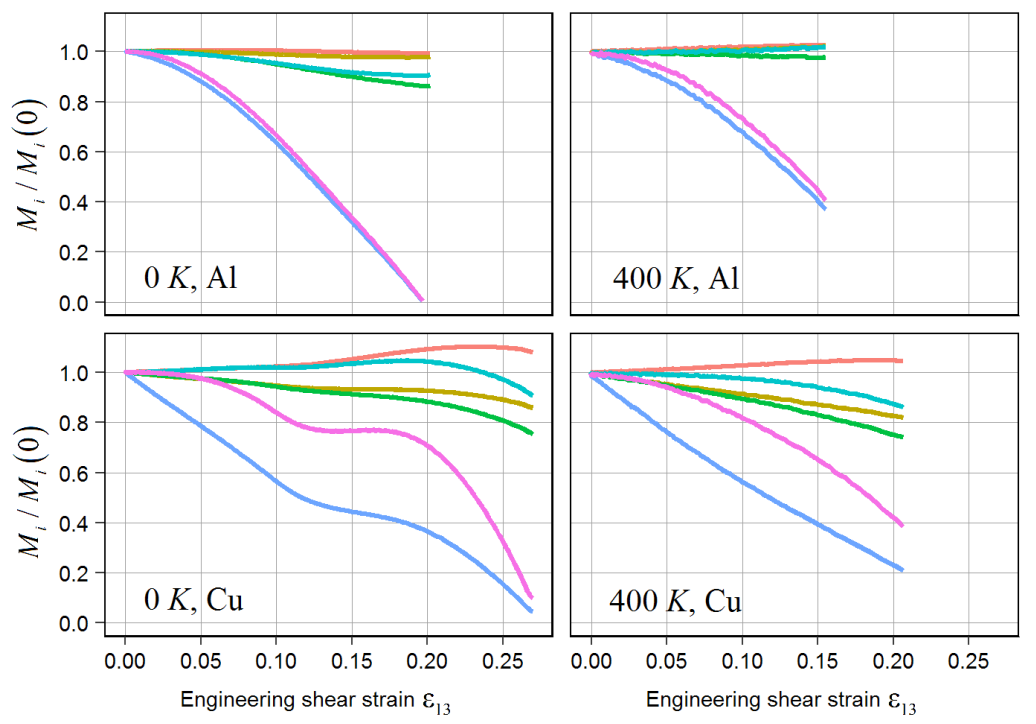

$\square \mathrm{M} 1=\mathrm{M} 2-\mathrm{M} 3=\mathrm{M} 4=\mathrm{M} 5=\mathrm{M} 6$

Fig. 2. (Color online) The evolution of the leading principal minors of matrix $B$ under applied shear strain for $\mathrm{Al}$ (upper panels) and $\mathrm{Cu}$ (bottom panels) at the minimal (left columns) and the maximal (right columns) tested temperatures. The values of $B_{i}$ and normalized to their values at zero strain. The curves are coloured according to the legend.

M5 in Al



Temperature, $\mathrm{K}-0-100-200-300-400$
M5 in $\mathrm{Cu}$

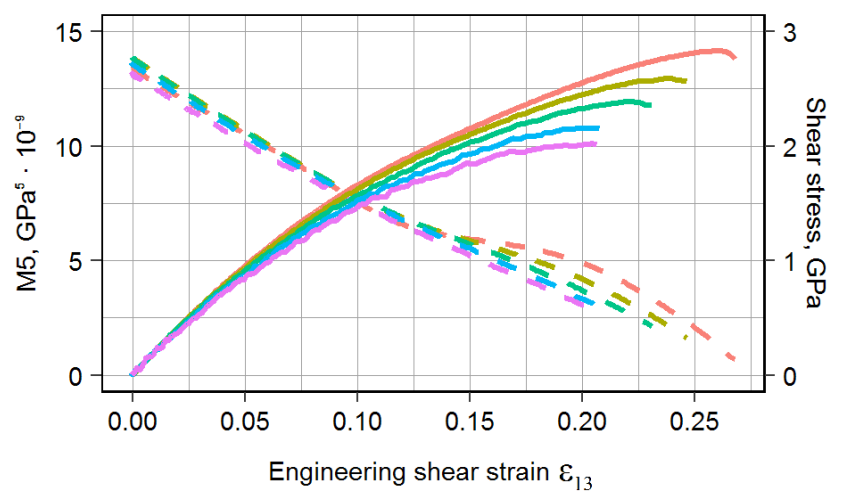

Temperature, $\mathrm{K}-0-100-200-300-400$
$\mathrm{M} 6$ in $\mathrm{Al}$



Temperature, $\mathrm{K}-0-100-200-300-400$
$\mathrm{M} 6$ in $\mathrm{Cu}$

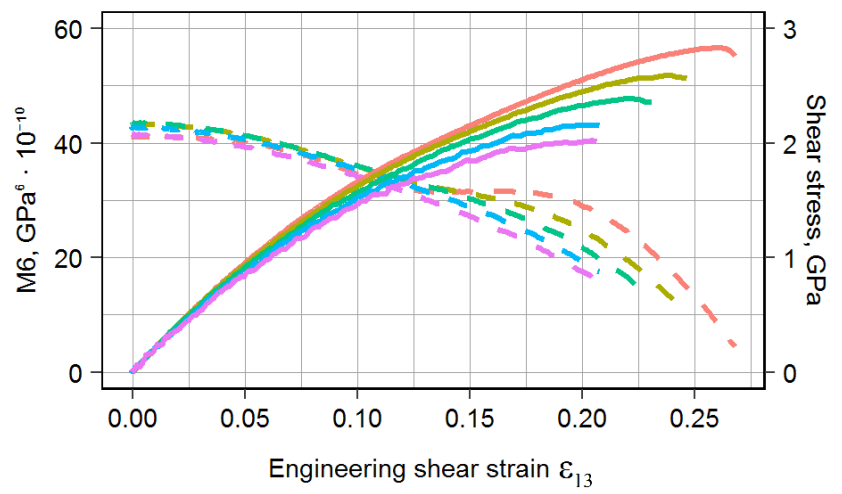

Temperature, $\mathrm{K}-0-100-200-300-400$

Fig. 3. (Color online) The evolution of $M_{5}$ (top panels) and $M_{6}$ (bottom panels) is shown by the dashed lines, while the evolution shear stress with solid lines. Results for temperatures $T=0,100,200,300$, and $400 \mathrm{~K}$ are presented for Al (left panels) and for $\mathrm{Cu}$ (right panels). 


\section{Conclusion}

In frame of the molecular dynamics method, the microscopic and macroscopic criteria of lattice stability are compared for two defect-free fcc metals ( $\mathrm{Al}$ and $\mathrm{Cu}$ ) subjected to shear deformation at different temperatures. The positive definiteness of the stiffness matrix is confirmed to be a macroscopic criterion for the lattice stability at $0 \mathrm{~K}$. At elevated temperatures the thermally assisted nucleation of lattice defects leads to an early loss of lattice stability, while the stiffness matrix is still positively definite. It is also shown that, as expected, the increase of temperature leads to a decrease of critical stress and critical strain for the two studied metals.

Acknowledgements. The work of D.S.V. was supported by the Russian Foundation for Basic Research, grant No. 17-02-00984. The work was partly supported by the State assignment of IMSP RAS.

\section{References}

1. C. Herring, J. K. Galt. Phys. Rev. 85, 1060 (1952). Crossref

2. B. $\mathrm{Wu}, \mathrm{A}$. Heidelberg, J.J. Boland. Nat. Mater. 4, 525 (2005). Crossref

3. A.M. Minor, S.A. Syed Asif, Z. Shan, E.A. Stach, E. Cyrankowski, T. J. Wyrobek, O.L. Warren. Nat. Mater. 5, 697 (2006). Crossref

4. M. Jahnátek, J. Hafner, M. Krajčí. Phys. Rev. B. 79, 224103 (2009). Crossref

5. D. Kiener, C. Motz, G. Dehm. Mater. Sci. Eng. A. 505, 79 (2009). Crossref

6. D. Kiener, W. Grosinger, G. Dehm, R. Pippan. Acta Mater. 56, 580 (2008). Crossref

7. S.W. Lee, S.M. Han, W. D. Nix. Acta Mater. 57, 4404 (2009). Crossref

8. Z.W. Shan, R. K. Mishra, S. A. Syed Asif, O.L. Warren, A. M. Minor. Nat. Mater. 7, 115 (2008). Crossref

9. A. T. Jennings, M. J. Burek, J. R. Greer. Phys. Rev. Lett. 104, 135503 (2010). $\underline{\text { Crossref }}$

10. G. Richter, K. Hillerich, D. S. Gianola, R. Monig, O. Kraft, C. A. Volkert. Nano Lett. 9, 3048 (2009). Crossref
11. H. Bei, S. Shim, E. P. George, M. K. Miller, E. G. Herbert, G. M. Pharr. Scr. Mater. 57, 397 (2007). Crossref

12. M. B. Lowry, D. Kiener, M.M. LeBlanc, C. Chisholm, J. N. Florando, J. W. Morris Jr., A. M. Minor. Acta Mater. 58, 5160 (2010). $\underline{\text { Crossref }}$

13. J.R. Morris, H. Bei, G.M. Pharr, E.P. George. Phys. Rev. Lett. 106, 165502 (2011). Crossref

14. S. Ogata, J. Li, N. Hirosaki, Y. Shibutani, S. Yip. Phys. Rev. B. 70, 104104 (2004). Crossref

15. T. Tsuru, Y. Kaji, D. Matsunaka, Y. Shibutani. Phys. Rev. B. 82, 024101 (2010). Crossref

16. R. Janisch, N. Ahmed, A. Hartmaier. Phys. Rev. B. 81, 184108 (2010). Crossref

17. T. Tsuru, Y. Shibutani. Phys. Rev. B. 75, 035415 (2007). Crossref

18. K. Kolluri, M. R. Gungor, D. Maroudas. Phys. Rev. B. 78, 195408 (2008). Crossref

19. K. Kolluri, M. R. Gungor, D. Maroudas. Appl. Phys. Lett. 94, 101911 (2009). Crossref

20. K. Kolluri, M. R. Gungor, D. Maroudas. J. Appl. Phys. 105, 093515 (2009). Crossref

21. Y. Umeno, M. Černý. Phys. Rev. B. 77, 100101 (R) (2008). Crossref

22. Y. Umeno, Y. Shiihara, N. Yoshikawa. J. Phys.: Condens. Matter. 23, 385401 (2011). Crossref

23. M. Černý, J. Pokluda. Comp. Mater. Sci. 50, 2257 (2011). Crossref

24. A. M. Iskandarov, S. V. Dmitriev, Y. Umeno. Phys. Rev. B. 84, 224118 (2011). Crossref

25. K. Mizushima, S. Yip, E. Kaxiras. Phys. Rev. B. 50, 14952 (1994). Crossref

26. Y.Mishin,D.Farkas, M. J.Mehl, D. A.Papaconstantopoulos. Phys. Rev. B. 59, 3393 (1999). Crossref

27. R. R. Zope, Y. Mishin. Phys. Rev. B. 68, 024102 (2003). Crossref

28. R. D. Boyer, J. Li, S. Ogata, S. Yip. Modell. Simul. Mater. Sci. Eng. 12, 1017 (2004). Crossref

29. A. M. Iskandarov, S. V. Dmitriev, Y. Umeno. Journal of Solid Mechanics and Materials Engineering. 6 (1), 29 (2012). $\underline{\text { Crossref }}$

30. M. Parrinello, A. Rahman. J. Appl. Phys. 52, 7182 (1981). $\underline{\text { Crossref }}$ 